\title{
Metal complexes of 1,10-phenanthroline-5,6-dione alter the susceptibility of the yeast Candida albicans to Amphotericin B and Miconazole
}

\author{
Ahmed Eshwika ${ }^{1}$, Barry Coyle ${ }^{2}$, Michael Devereux ${ }^{3}$, Malachy McCann ${ }^{2} \&$ Kevin Kavanagh ${ }^{1 \text {,* }}$ \\ ${ }^{1}$ Medical Mycology Unit, NICB, Department of Biology, National University of Ireland Maynooth, Co. Kildare, \\ Ireland; ${ }^{2}$ Department of Chemistry, National University of Ireland Maynooth, Co. Kildare, Ireland; ${ }^{3}$ Dublin \\ Institute for Technology, Cathal Brugha St., Dublin 1; *Author for correspondence (Tel: 353-1-708 3859, Fax: \\ 353-1-708 3845, E-mail: kevin.kavanagh@may.ie.)
}

Received 15 October 2003; Accepted 28 November 2003

\section{Abstract}

Growth of the pathogenic yeast Candida albicans in sub-MIC (minimum inhibitory concentration) levels of $\mathrm{Cu}\left(\mathrm{ClO}_{4}\right)_{2} \cdot 6 \mathrm{H}_{2} \mathrm{O}$ and $\left.[\mathrm{Cu} \text { (phendio })_{3}\right]\left(\mathrm{ClO}_{4}\right)_{2} \cdot 4 \mathrm{H}_{2} \mathrm{O}$ (phendio = 1,10-phenanthroline-5,6-dione) increased the concentration of miconazole and amphotericin $\mathrm{B}$ required to achieve the $\mathrm{MIC}_{90}$ whereas pre-growth in $\mathrm{AgClO}_{4}$ and $\left[\mathrm{Ag}(\text { phendio })_{2}\right] \mathrm{ClO}_{4}$ resulted in a small decrease in the relevant $\mathrm{MIC}_{90}$ values. The copper complexes reduce the oxygen consumption of $C$. albicans while the silver complexes increase oxygen consumption. In addition, pregrowth of cells in the copper complexes resulted in a lower ergosterol content while the silver complexes induced an elevation in ergosterol synthesis.

The ability of copper and silver complexes to alter the susceptibility of $C$. albicans to miconazole and amphotericin B may be influenced by their action on respiration, since reduced respiration rates correlate with reduced cellular ergosterol which is the target for amphotericin B. Lower levels of ergosterol have previously been associated with elevated tolerance to this drug. In the case of reduced sensitivity to miconazole, tolerance may be mediated by lower ergosterol synthesis giving rise to fewer toxic side products once biosynthesis is inhibited by miconazole.

Abbreviations: phendio $=1,10$-phenanthroline-5,6-dione phen $=1,10$-phenanthroline

\section{Introduction}

The yeast Candida albicans is responsible for a range of superficial and systemic diseases in the immunocompromised patient. Conventional therapies for the control of these diseases rely upon the use of azole and polyene drugs which target ergosterol biosynthesis and alter membrane permeability, respectively (White et al., 1998, Abu Salah, 1996). In recent years, the appearance of fungal strains manifesting resistance to conventional drugs (Canuto \& Rodero, 2002) has prompted the search for novel anti-fungals with modes of action distinct to the existing range of anti-fungals.

Metal-based drugs represent a novel group of antifungal agents with potential applications for the control of fungal infections. Previous work in our laboratories has demonstrated that in RPMI medium at $37^{\circ} \mathrm{C}$ the metal-based drugs $\left[\mathrm{Cu}(\text { phen })_{2}(\right.$ mal $\left.)\right] \cdot 2 \mathrm{H}_{2} \mathrm{O}$, $\left[\mathrm{Mn}(\text { phen })_{2}(\mathrm{mal})\right] \cdot 2 \mathrm{H}_{2} \mathrm{O}$ and $\left[\mathrm{Ag}(\text { phen })_{2}\right] \mathrm{ClO}_{4}$ (phen $=1,10$-phenanthroline) inhibit the growth of $C$. albicans by around $95 \%$ at a concentration of $5 \mu \mathrm{g} / \mathrm{ml}$ (McCann et al. 2000; Coyle et al. 2003a). It was established that both metal-free phen and the metalphen complexes affect mitochondrial function, retard the synthesis of cytochromes $b$ and $c$ and uncouple respiration. Treatment of fungal cells with the $\mathrm{Cu}(\mathrm{II})$ and $\mathrm{Ag}(\mathrm{I})$ complexes resulted in a reduced amount of ergosterol in the cell membrane and subsequent increase in its permeability. Cells exposed to metal-free phen and the $\mathrm{Cu}$ (II) and $\mathrm{Mn}$ (II) complexes (but not the $\mathrm{Ag}(\mathrm{I}$ ) complex) demonstrated an elevation in oxygen uptake. The general conclusion was that the drugs damage mitochondrial function and uncouple respiration. Fur- 
thermore, the fact that the drugs were not uniformly active suggested that their bioactivity had a degree of metal-ion dependency.

More recently, metal-free phendio (phendio $=$ 1,10-phenanthroline-5,6-dione) and the $\mathrm{Ag}(\mathrm{I})$ complex $\left[\mathrm{Ag}(\text { phendio })_{2}\right] \mathrm{ClO}_{4}$ have been shown to cause extensive, non-specific DNA cleavage to $C$. albicans, disrupt cell division and induce gross distortions in fungal cell morphology (Coyle et al., 2003b). Preliminary experiments on cultured human cancer cells produced $\mathrm{IC}_{50}$ values of $0.008 \mu \mathrm{g} / \mathrm{ml}(0.04 \mu \mathrm{M})$ and $0.025 \mu \mathrm{g} / \mathrm{ml}(0.40 \mu \mathrm{M})$ for metal-free phendio and $\left.[\mathrm{Ag} \text { (phendio })_{2}\right] \mathrm{ClO}_{4}$, respectively (Coyle et al. 2003b). Studies by Igdaloff et al. (1983) revealed that both phendio and its isomer, 1,7-phenanthroline-5,6dione, inhibit the growth of $\mathrm{S} 49$ mouse lymphona cells and S110 mouse cells, and although it was postulated that inhibition of DNA and RNA syntheses were major components of the cytotoxic effects the phenanthrolines were presumed to have more than one mode of action.

Metal-based drugs have well established fungistatic and fungicidal effects and the aim of the work presented here was to evaluate the possibility of using $\mathrm{Cu}$ (II) and $\mathrm{Ag}$ (I) phendio complexes in combination with azole and polyene drugs for the control of C. albicans.

\section{Materials and methods}

\section{Fungal isolate and culture conditions}

C. albicans MEN (a kind gift from Dr. David Kerridge, Cambridge, UK) was grown to the stationary phase (approximately $1.5 \times 10^{8}$ cells $/ \mathrm{ml}$ ) at $30^{\circ} \mathrm{C}$ overnight in YEPD broth $(2 \%(\mathrm{w} / \mathrm{v})$ glucose (Sigma Aldrich Chemical Co., Dorset, UK), 2\% (w/v) bacteriological peptone (Sigma Aldrich) and 1\% (w/v) yeast extract (Sigma Aldrich)) in an orbital incubator at $200 \mathrm{rpm}$.

\section{Drugs}

Chemicals were obtained from commercial sources and used without further purification. $\mathrm{Cu}\left(\mathrm{ClO}_{4}\right)_{2} \cdot 6 \mathrm{H}_{2} \mathrm{O}$ was purchased from Sigma Aldrich and used without further purification. $\left.[\mathrm{Cu} \text { (phendio })_{3}\right]\left(\mathrm{ClO}_{4}\right)_{2} \cdot 4 \mathrm{H}_{2} \mathrm{O}$ and $\left.[\mathrm{Ag} \text { (phendio })_{2}\right] \mathrm{ClO}_{4}$ were synthesized in accordance with the procedures outlined in McCann et al. (2003).
Anti-Candida susceptibility testing of metal-based drugs

Solutions of water-soluble copper and silver complexes were prepared by dissolving $0.02 \mathrm{~g}$ of the solid in sterile distilled water to yield a stock solution of $200 \mu \mathrm{g} / \mathrm{ml}$. The solutions were filter sterilised using a Millipore membrane filter $(0.45 \mu \mathrm{m})$. Stationary phase cultures of $C$. albicans were harvested by centrifugation $(2220 \times \mathrm{g}$ for $5 \mathrm{~min}$ in a Beckmann GS-6 centrifuge), washed twice with PBS and resuspended at a final density of $1 \times 10^{6}$ cells $/ \mathrm{ml}$. Cell suspension $(100 \mu \mathrm{l})$ was added to each well of a 96-well microtitre plate except the first column (control medium). Serial dilutions of metal-based drugs were added to rows of wells to construct a concentration gradient from 50$0.78 \mu \mathrm{g} / \mathrm{ml}$ and the plates were incubated at $30^{\circ} \mathrm{C}$ for $24 \mathrm{~h}$. The absorbance at $450 \mathrm{~nm}$ was determined using a MRX spectrophotometer (Dynax Technology, Chantilly, VA, USA) and the concentration that was capable of inhibiting growth by $90 \%\left(\mathrm{MIC}_{90}\right)$ relative to the control was calculated.

\section{Amphotericin B and miconazole susceptibility testing}

Yeast cultures were grown to the stationary phase in antibiotic medium 3 (AB 3, Oxoid) overnight at $30^{\circ} \mathrm{C}$ and $200 \mathrm{rpm}$, harvested by centrifugation and diluted to $1 \times 10^{6} / \mathrm{ml}$. Cells $\left(1 \times 10^{5}\right.$ in $\left.100 \mu \mathrm{l}\right)$ were added to each row of a 96-well plate containing amphotericin B in serial dilutions (Sigma-Aldrich) from $2.5-0.0048 \mu \mathrm{g} / \mathrm{ml}$ in $\mathrm{AB} 3$ medium.

Miconazole susceptibility testing was performed using stationary phase $C$. albicans that had been grown in RPMI medium overnight (Sigma Aldrich). Cells $\left(100 \mu \mathrm{l}\right.$ of $\left.1 \times 10^{6} / \mathrm{ml}\right)$ were added to each row of a 96-well plate containing miconazole, serially diluted in RPMI medium from $20-0.19 \mu \mathrm{g} / \mathrm{ml}$.

All plates were incubated at $30^{\circ} \mathrm{C}$ for $24 \mathrm{~h}$ and the optical density was read at $450 \mathrm{~nm}$ using a MRX spectrophotometer (Dynax Technology, Chantilly, VA, USA).

\section{Oxygen consumption}

Cells were grown in YEPD broth supplemented with sub-MIC levels of silver or copper complexes at $30^{\circ} \mathrm{C}$ for $24 \mathrm{~h}$, harvested by centrifugation and re-suspended at a density of $1 \times 10^{8} / \mathrm{ml}$ in phosphate buffered saline (PBS, pH 7.2). A Clark Type oxygen electrode (Ranks Brothers, Cambridge, UK) was employed to determine the respiration rate of cells. The rate of oxygen 


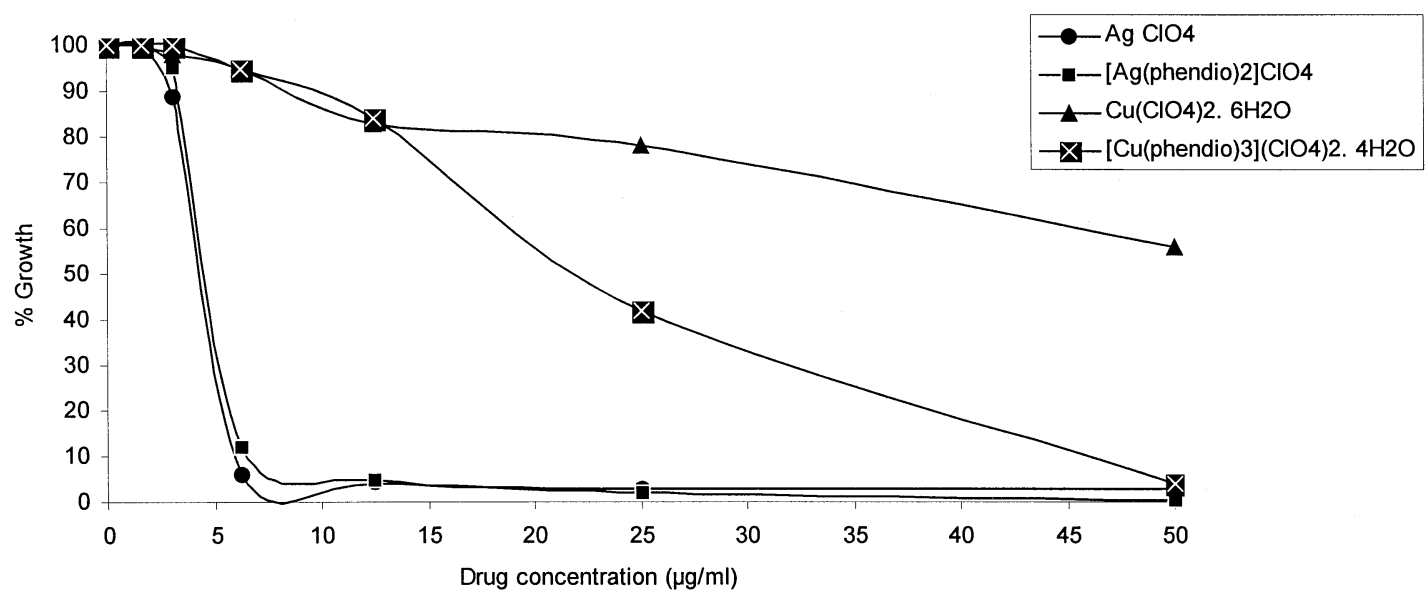

Fig 1. Effect of metal-based drugs on the growth of C. albicans. Cells of C. albicans were exposed to increasing concentrations of MBD and the effect on growth after $24 \mathrm{~h}$ incubation was determined.

consumption is expressed as the number of $\mu$ moles of oxygen consumed per thirty sec per $1 \times 10^{8}$ cells.

\section{Sterol extraction and analysis}

Sterols were extracted according to the method of Arthington-Skaggs et al. (1999). Stationary phase cells (1.3 g wet weight) were harvested and washed with PBS ( $\mathrm{pH} 7.2$ ). Cells were re-suspended in $20 \%$ $(\mathrm{w} / \mathrm{v}) \mathrm{KOH}$ and $60 \%(\mathrm{v} / \mathrm{v})$ ethanol and placed in a shaking water bath $\left(80-90^{\circ} \mathrm{C}\right)$ for $1.5 \mathrm{~h}$. Heptane was added to the solution which was then agitated for $10 \mathrm{sec}$ and the aqueous layer removed. The sterol content of the hexane layer was quantified using a dual beam spectrophotometer over the range $250-300 \mathrm{~nm}$.

\section{Statistical analysis}

The Kruskal-Wallis test was performed, where appropriate, on all results using the SigmaStat Statistical Analysis System (Version 1.00). Values are presented as $\pm \mathrm{SE}$ of the mean of data from three independent experiments.

\section{Results}

The effect of selected $\mathrm{Cu}(\mathrm{II})$ and $\mathrm{Ag}(\mathrm{I})$ phendio complexes on the growth of $C$. albicans was assessed. The results indicate (Figure 1) that $\mathrm{AgClO}_{4}$ and $\left.[\mathrm{Ag} \text { (phendio })_{2}\right] \mathrm{ClO}_{4}$ display $\mathrm{MIC}_{90}$ values of approximately $6.0 \mu \mathrm{g} / \mathrm{ml}$ while $\mathrm{Cu}\left(\mathrm{ClO}_{4}\right)_{2} \cdot 6 \mathrm{H}_{2} \mathrm{O}$ and $\left.[\mathrm{Cu} \text { (phendio })_{3}\right]\left(\mathrm{ClO}_{4}\right)_{2} \cdot 4 \mathrm{H}_{2} \mathrm{O}$ display $\mathrm{MIC}_{90}$ values of $>50$ and $46 \mu \mathrm{g} / \mathrm{ml}$, respectively. In all subsequent assays, concentrations corresponding to $1 / 4$ $\mathrm{MIC}_{90}$ values of these complexes values were employed i.e. $\mathrm{AgClO}_{4}$ and $\left[\mathrm{Ag}(\text { phendio })_{2}\right] \mathrm{ClO}_{4}$ at a concentration of $1.5 \mu \mathrm{g} / \mathrm{ml}$ and $\mathrm{Cu}\left(\mathrm{ClO}_{4}\right)_{2} \cdot 6 \mathrm{H}_{2} \mathrm{O}$ and $\left.[\mathrm{Cu} \text { (phendio })_{3}\right]\left(\mathrm{ClO}_{4}\right)_{2} \cdot 4 \mathrm{H}_{2} \mathrm{O}$ at concentrations of $12.5 \mu \mathrm{g} / \mathrm{ml}$ and $11.5 \mu \mathrm{g} / \mathrm{ml}$, respectively. Sub-MIC values were employed in all subsequent assays so that any effect on drug susceptibility would not be due to the fungistatic effects of these compounds

Experiments were performed to determine whether pre-growth of $C$. albicans in the presence of different metal complexes affected the subsequent susceptibility of cells to azole and/or polyene drugs. Cells were pre-grown in medium supplemented with $1 / 4 \mathrm{MIC}_{90}$ of the $\mathrm{Cu}(\mathrm{II})$ and $\mathrm{Ag}(\mathrm{I})$ phendio complexes for $24 \mathrm{~h}$ at $30^{\circ} \mathrm{C}$ and harvested by centrifugation. Anti-fungal susceptibility assays were performed as described. The results (Figure 2) indicate that pre-growth of $C$. albicans in medium supplemented with $12.5 \mu \mathrm{g} / \mathrm{ml} \mathrm{Cu}\left(\mathrm{ClO}_{4}\right)_{2} \cdot 6 \mathrm{H}_{2} \mathrm{O}$ or $\left.11.5 \mu \mathrm{g} / \mathrm{ml}[\mathrm{Cu} \text { (phendio) })_{3}\right]\left(\mathrm{ClO}_{4}\right)_{2} \cdot 4 \mathrm{H}_{2} \mathrm{O}$ significantly decreases the susceptibility of $C$. albicans to miconazole $(\mathrm{p}<0.001)$ (control $\mathrm{MIC}_{90}=$ $7.94 \pm 1.2 \mu \mathrm{g} / \mathrm{ml}$, cells pre-grown in $1 / 4 \mathrm{MIC}$ $\mathrm{Cu}\left(\mathrm{ClO}_{4}\right)_{2} \cdot 6 \mathrm{H}_{2} \mathrm{O} \mathrm{MIC}_{90}=10.9 \pm 0.2 \mu \mathrm{g} / \mathrm{ml}$, cells pre-grown in $\left.1 / 4 \mathrm{MIC}[\mathrm{Cu} \text { (phendio })_{3}\right]\left(\mathrm{ClO}_{4}\right)_{2} \cdot 4 \mathrm{H}_{2} \mathrm{O}$ $\left.\mathrm{MIC}_{90}=11.4 \pm 0.3 \mu \mathrm{g} / \mathrm{ml}\right)$. In the case of the silver complexes, pre-growth of $C$. albicans in $1.5 \mu \mathrm{g} / \mathrm{ml}$ $\mathrm{AgClO}_{4}$ or $\left.[\mathrm{Ag} \text { (phendio) })_{2}\right] \mathrm{ClO}_{4}$ increases the susceptibility of the cells to miconazole. Cells pre-grown in $1 / 4 \mathrm{MIC}_{90} \mathrm{AgClO}_{4}$ show a miconazole $\mathrm{MIC}_{90}$ value of $3.24 \pm 0.09 \mu \mathrm{g} / \mathrm{ml}$ while those pre-grown in 


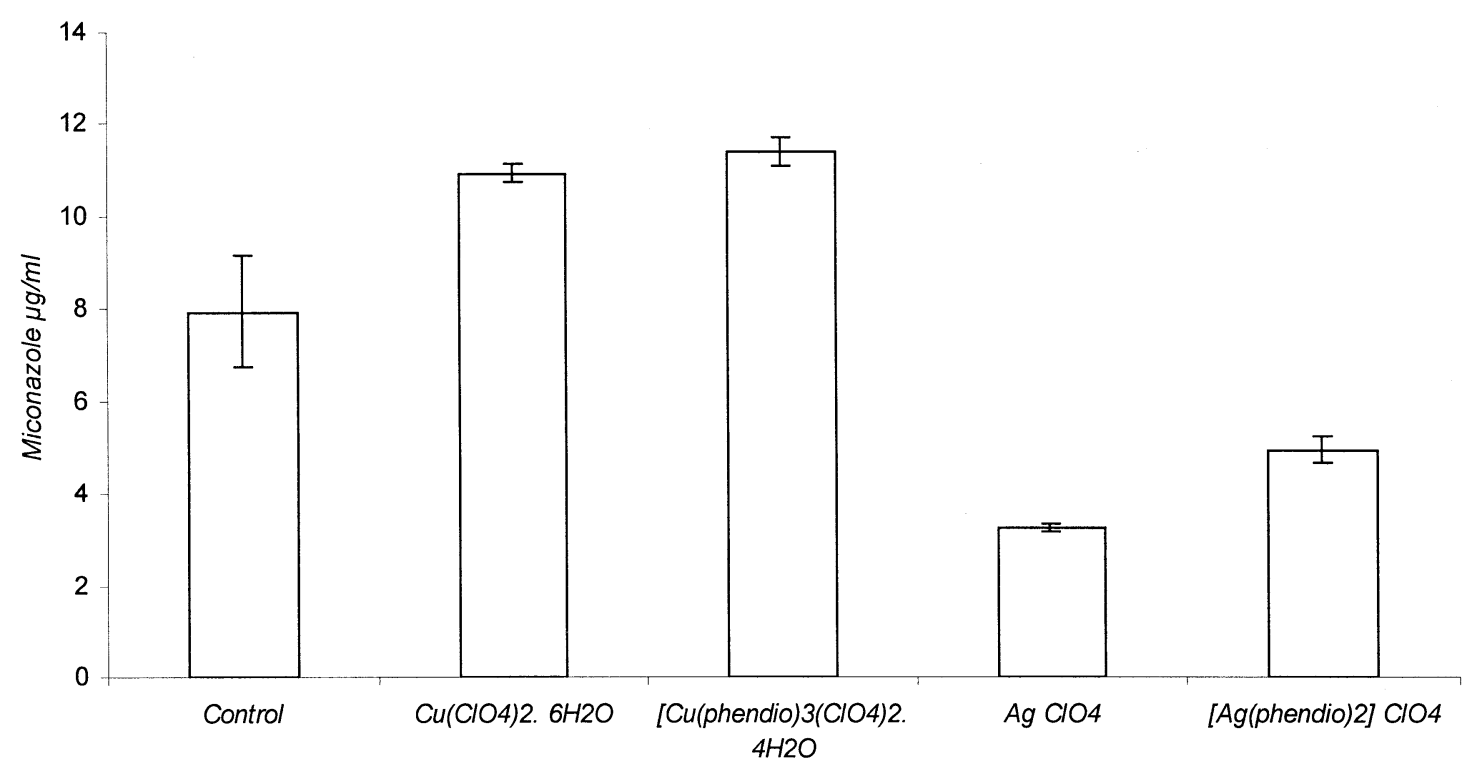

Fig 2. Susceptibilities to Miconazole of C. albicans pre-grown in the presence of sub-MIC 90 levels of metal complexes. The susceptibility of C. albicans to miconazole was determined after cells had been first pre-grown in sub- $\mathrm{MIC}_{90}$ levels of metal-based drug.

$1 / 4 \mathrm{MIC}_{90}\left[\mathrm{Ag}\right.$ (phendio) $\left.{ }_{2}\right] \mathrm{ClO}_{4}$ demonstrate a $\mathrm{MIC}_{90}$ value of $4.95 \pm 0.27 \mu \mathrm{g} / \mathrm{ml}$.

The susceptibility of $C$. albicans to the polyene drug amphotericin B was also affected following pre-growth of the cells in medium supplemented with copper or silver complexes at $1 / 4 \mathrm{MIC}_{90}$ values (Figure 3). In the case of pre-growth in $1 / 4$ $\mathrm{MIC}_{90} \mathrm{Cu}\left(\mathrm{ClO}_{4}\right)_{2} \cdot 6 \mathrm{H}_{2} \mathrm{O}$ the amount of amphotericin $\mathrm{B}$ required to achieve the $\mathrm{MIC}_{90}$ increases to $0.029 \pm 0.007 \mu \mathrm{g} / \mathrm{ml}$ from $0.024 \pm 0.003 \mu \mathrm{g} / \mathrm{ml}$ (control) and following pre-growth in a similar concentration of $\left.[\mathrm{Cu} \text { (phendio })_{3}\right]\left(\mathrm{ClO}_{4}\right)_{2} \cdot 4 \mathrm{H}_{2} \mathrm{O}$ increases to $0.03 \pm 0.003 \mu \mathrm{g} / \mathrm{ml}(\mathrm{p}=0.238)$. In the case of pre-exposure to the silver complexes there is a decrease in the amount of amphotericin B required to achieve the $\mathrm{MIC}_{90}$. Pre-growth of $C$. albicans in either of the silver complexes reduces the amount of amphotericin B required to achieve the $\mathrm{MIC}_{90}$ from $0.024 \pm 0.003 \mu \mathrm{g} / \mathrm{ml}$ to $0.019 \pm 0.001 \mu \mathrm{g} / \mathrm{ml}$ $(\mathrm{p}=0.238)$ (Figure 3).

Azoles, such as miconazole, inhibit the action of lanosterol $14 \alpha$-demethylase which controls an essential intermediate step in the biosynthesis of ergosterol (White et al., 1998, Daum et al., 1998). In contrast, polyenes, such as amphotericin B, bind to ergosterol in the fungal cell membrane creating pores through which cell constituents may escape (Abu Salah, 1996). Ergosterol biosynthesis is an oxygen dependent process and also requires NADPH which is synthesised in the aerobically respiring mitochondrion. Consequently, experiments were performed to establish whether the altered susceptibility of $C$. albicans to miconazole and amphotericin B was due to the ability of the copper or silver complexes to alter respiration. The results (Figure 4) demonstrate that pre-growth of cells in $1 / 4$ $\mathrm{MIC}_{90}$ of the copper complexes $\left(\mathrm{Cu}\left(\mathrm{ClO}_{4}\right)_{2} \cdot 6 \mathrm{H}_{2} \mathrm{O}\right.$ and $\left.\left.[\mathrm{Cu} \text { (phendio })_{3}\right]\left(\mathrm{ClO}_{4}\right)_{2} \cdot 4 \mathrm{H}_{2} \mathrm{O}\right)$ results in a reduction in the cellular respiration rate $(\mathrm{p}<0.001)$ whereas growth of cells in the presence of the silver complexes $\left(\mathrm{AgClO}_{4}\right.$ and $\left.\left[\mathrm{Ag}(\text { phendio })_{2}\right] \mathrm{ClO}_{4}\right)$ increases the respiration rate of $C$. albicans $(\mathrm{p}<0.001)$.

The ergosterol biosynthetic pathway is the target of the azole drugs (White et al. 1998) whilst polyenes bind ergosterol in the cell membrane and create pores (Abu Salah, 1996). Quantification of ergosterol in cells grown in medium supplemented with sub $\mathrm{MIC}_{90}$ concentrations of the metal-based drugs demonstrated that growth in the presence of copper complexes resulted in a reduced ergosterol content, while growth in medium supplemented with the silver complexes resulted in an increase in cellular ergosterol (Figure 5). Interestingly, those compounds that increase the respiration rate $\left(\mathrm{AgClO}_{4}\right.$ and $\left.\left[\mathrm{Ag}(\text { phendio })_{2}\right] \mathrm{ClO}_{4}\right)$ also cause an increase in ergosterol content while those that depress respiration $\left(\mathrm{Cu}\left(\mathrm{ClO}_{4}\right)_{2} \cdot 6 \mathrm{H}_{2} \mathrm{O}\right.$ and $\left.\left[\mathrm{Cu}(\text { phendio })_{3}\right]\left(\mathrm{ClO}_{4}\right)_{2} \cdot 4 \mathrm{H}_{2} \mathrm{O}\right)$ lead to a reduction in ergosterol content. 


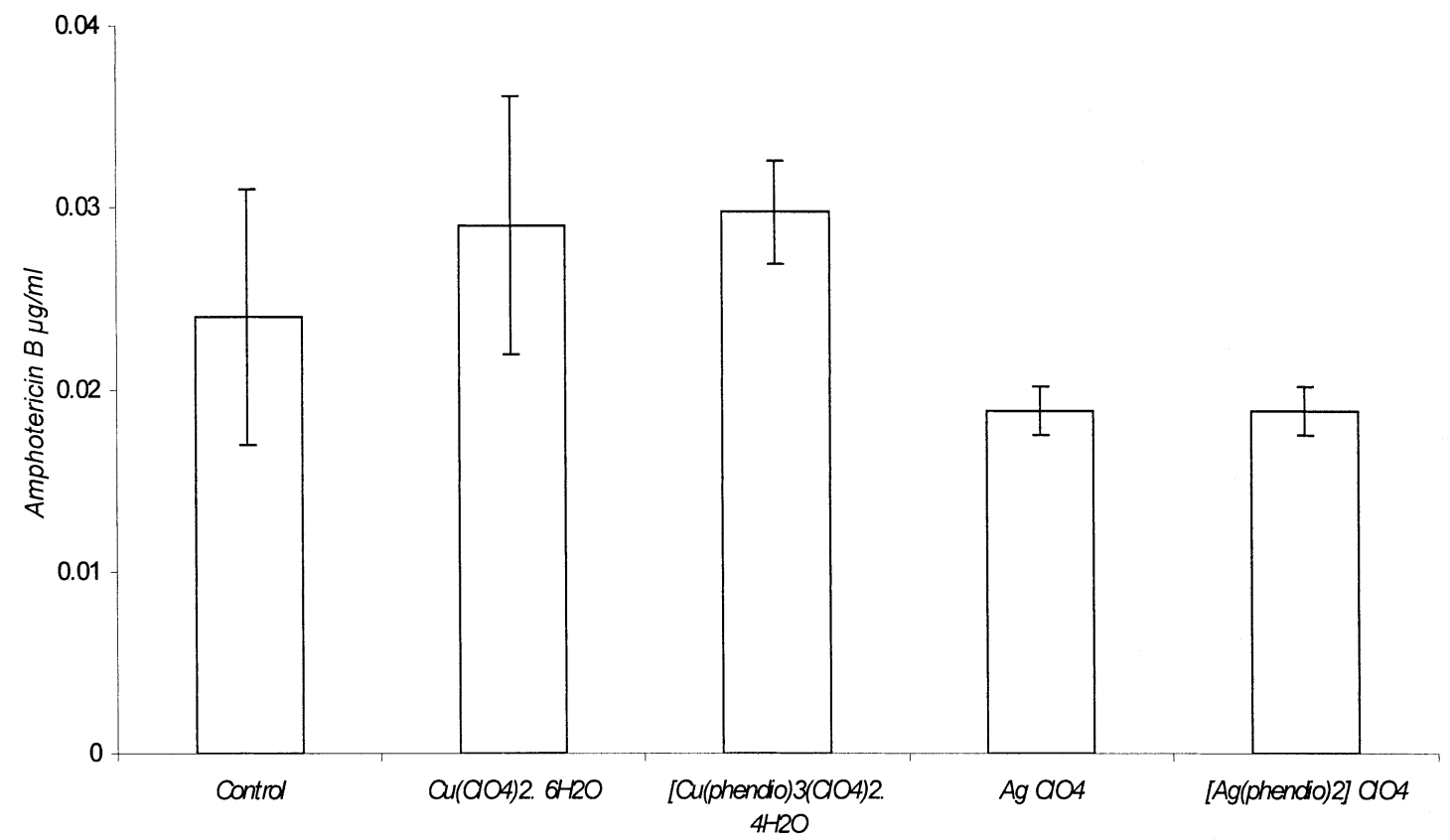

Fig 3. Susceptibilities to Amphotericin B of C. albicans pre-grown in the presence of sub-MIC 90 levels of metal complexes. The susceptibility of $C$. albicans to amphotericin B was determined after cells had been first pre-grown in sub- $\mathrm{MIC}_{90}$ levels of metal-based drug.

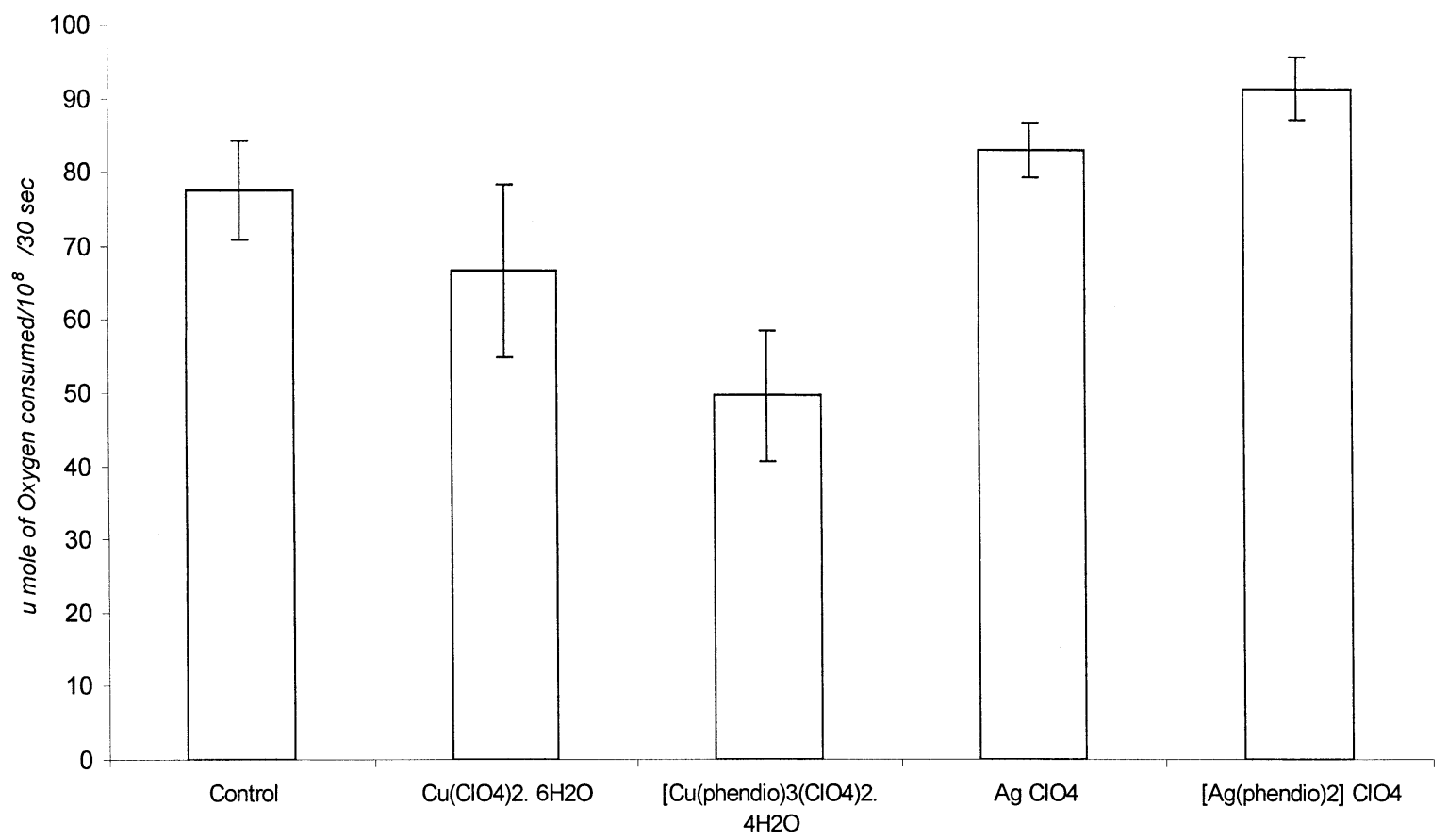

Fig 4. Respiration rates of C. albicans cells pre-grown in sub-MIC 90 levels of metal complexes. The oxygen consumption rates of $C$. albicans cell pre-grown in sub-MIC $\mathrm{C}_{90}$ levels of metal-based drug were determined using a Rank Oxygen electrode and expressed as $\mu$ moles of oxygen consumed per $10^{8}$ cells per $30 \mathrm{sec}$. 


\section{NEW ARTWORK PLEASE!}

Fig 5. Ergosterol profiles of C. albicans cells pre-grown in sub-MIC 90 levels of metal complexes. (Representative figure). The relative amounts of ergosterol in cells pre-treated with sub-MIC 90 concentrations of metal-based drug were ascertained spectrophotometrically over the range $250-300 \mathrm{~nm}$.

\section{Discussion}

Metal-based drugs represent a novel group of antimicrobial agents with potential therapeutic applications (Coyle et al. 2003a; McCann et al. 2000). With the advent of fungal isolates manifesting resistance to azole and polyene drugs (Canuto \& Rodero, 2002) there is a requirement for new drugs with alternative modes of action or with the ability to increase the efficacy of existing prescription drugs. Many metalbased drugs display modes of action distinct to those of the prescription anti-fungals (Coyle et al. 2003a) possibly allowing their use where resistance to conventional drugs has emerged (White et al. 1998). In addition, their different mode(s) of action may be utilised by employing such drugs in conjunction with existing drugs in order to target two (or more) sites within the fungal cell and thus raising the possibility of achieving the same therapeutic effect by reducing the required amount of an azole or polyene drug. Conventional anti-fungal drugs such as polyenes or azoles target ergosterol in the cell membrane or the ergosterol biosynthetic pathway, respectively. In the work presented here we have evaluated the ability of $\mathrm{Cu}$ (II) and $\mathrm{Ag}(\mathrm{I})$ phendio complexes to alter the susceptibility of $C$. albicans to conventional azole and polyene drugs.

The copper and silver complexes evaluated here demonstrated fungistatic properties but for this work sub-MIC 90 values were employed to ascertain their effect on the sensitivity of $C$. albicans to the conventional antifungal drugs. Sub-MIC levels were chosen to ensure that the observed effect was not due to the fungistatic actions of the metal complex. When cells are pre-grown in sub-MIC 90 levels of the silver or copper complexes and then assessed for their response to miconazole or amphotericin B there is evidence of alterations in susceptibility. Pre-growth in $1 / 4 \mathrm{MIC}_{90}$ $\mathrm{Cu}\left(\mathrm{ClO}_{4}\right)_{2} \cdot 6 \mathrm{H}_{2} \mathrm{O}$ or $\left.[\mathrm{Cu} \text { (phendio })_{3}\right]\left(\mathrm{ClO}_{4}\right) \cdot 4 \mathrm{H}_{2} \mathrm{O}$ increased the tolerance of $C$. albicans to miconazole and amphotericin $\mathrm{B}$, whereas pre-growth in equivalent concentrations of $\mathrm{AgClO}_{4}$ and $\left.[\mathrm{Ag} \text { (phendio) })_{2} \mathrm{ClO}_{4}\right]$ lowers the susceptibility of $C$. albicans to miconazole and amphotericin B.

The alteration in susceptibility to miconazole and amphotericin B may occur due to the fact that the metal complexes which inhibit respiration (i.e. $\mathrm{Cu}\left(\mathrm{ClO}_{4}\right)_{2} \cdot 6 \mathrm{H}_{2} \mathrm{O}$ and $\left.\left.[\mathrm{Cu} \text { (phendio })_{3}\right]\left(\mathrm{ClO}_{4}\right)_{2} \cdot 4 \mathrm{H}_{2} \mathrm{O}\right)$ also cause a reduction in the cellular ergosterol content. Azoles, such as miconazole, target lanosterol $14 \alpha$-demethylase which regulates an intermediate step in ergosterol biosynthesis (Morschhauser, 2002). The azoles can kill cells by inhibiting this enzyme which subsequently leads to a decrease in ergosterol content of the fungal cell membrane. In addition, the inhibition of the action of $\Delta^{5,6}$-sterol desaturase by fluconazole leads to the accumulation of toxic intermediates (such as $14 \alpha$-methylfecosterol) which may prove fatal to the fungal cell (Geber et al. 1995). The altered susceptibility to miconazole may be due to reduced ergosterol biosynthesis resulting in fewer toxic side products being formed once the action of the demethylase has been inhibited by miconazole. Enhanced ergosterol biosynthesis may inadvertently lead to greater production of toxic side-products once the azole-mediated inhibition of sterol biosynthesis occurs.

Reduced levels of ergosterol in the fungal cell membrane provide fewer binding sites for amphotericin B. Consequently a higher concentration of amphotericin B is required to retard the growth of the cell. Reductions in sterol levels in C. albicans have been identified previously as a mechanism for increased growth in the presence of amphotericin B (Kelly et al. 1997; White et al. 1998). Disruptions of the genes in the ergosterol biosynthesis pathway cause a decrease in ergosterol in C. glabrata and an increase in drug tolerance, particularly to amphotericin B (Geber et al. 1995; Vazquez et al. 1996). Inhibition of respiration in $C$. albicans by erythromycin leads to a drop in ergosterol and a concomitant increase in tolerance to amphotericin B (Geraghty \& Kavanagh, 2003a). In addition, disruption of mitochondrial function leads to 
tolerance to amphotericin B due to depleted ergosterol synthesis (Geraghty \& Kavanagh, 2003b).

The requirement for a functional mitochondrion in ergosterol biosynthesis is well characterised and arises from the provision of NADPH for squalene dimerisation (Parks \& Casey, 1995). In addition, Ergl encodes squalene epoxidase, which converts squalene to 2,3-oxidosqualene. This is an oxygen-dependent step, and in a cell with reduced respiration there would a consequent reduction in the synthesis of ergosterol (Daum et al. 1998), thus leading to the reduced ergosterol content evident in cells exposed to the copper complexes.

An increase in respiration, as evident when cells are pre-grown in the presence of $\mathrm{AgClO}_{4}$ and $[\mathrm{Ag} \text { (phendio })_{2} \mathrm{ClO}_{4}$ stimulates ergosterol production. Thus, there is more ergosterol for amphotericin B to bind and, as a consequence, lowering the amount of the polyene necessary for inhibition of cell growth. In the case of the altered sensitivity to miconazole, the silver complexes stimulate respiration and ergosterol biosynthesis and consequently may indirectly lead to the generation of more toxic side-products once the cells are exposed to miconazole.

The work presented here demonstrates that using sub-MIC levels of copper or silver dione complexes it is possible to alter the amount of an azole or polyene drug required to inhibit the growth of $C$. albicans. This effect appears to be mediated through alterations in the respiration rate of the cell, thereby influencing the amount of ergosterol synthesis. This opens the possibility of utilising, non-toxic levels of silver complexes to stimulate respiration and ergosterol production with a concomitant reduction in the amount of miconazole or amphotericin B required to achieve the relevant $\mathrm{MIC}_{90}$.

\section{Acknowledgement}

This work was supported by a grant from the Department of Education, Libya.

\section{References}

Abu-Salah KM. 1996 Amphotericin B: an update. Brit J Biomed Sci 53, 122-133.
Arthington-Skaggs BA, Warnock DW, Morrison CJ. 1999 Quantitation of ergosterol content: Novel methods for determination of fluconazole susceptibility of Candida albicans. J Clin Microbiol 37, 3332-3337.

Canuto M, Rodero FG. 2002 Antifungal drug resistance to azole and polyenes. Lancet (Infect Dis) 2, 550-562.

Coyle B, Kavanagh K, McCann M, Devereux M, Geraghty M. 2003a Mode of anti-fungal activity of 1,10-phenanthroline and its $\mathrm{Cu}(\mathrm{II}), \mathrm{Mn}(\mathrm{II})$ and $\mathrm{Ag}(\mathrm{I})$ complexes. Biometals 16, 321-329.

Coyle B, Kinsella P, McCann M, Devereux M, O'Connor R, Clynes M, Kavanagh K. 2003b Induction of apoptosis in yeast and mammalian cells by exposure to 1,10-phenanthroline metal complexes. Toxicology in Vitro (in press).

Daum G, Lees ND, Bard M, Dickson R. 1998 Biochemistry, cell biology and molecular biology of lipids of Saccharomyces cerevisiae. Yeast 14, 1471-1510.

Geber A, Hitchcock CA, Swartz JE, Pullen FS, Marsden KE, Kwon-Chung KJ, Bennett JE. 1995 Deletion of the Candida glabrata ERG3 and ERG11 genes: Effect on cell viability, cell growth, sterol composition and antifungal susceptibility. Antimicrob Agen Chemother 39, 2708-2717.

Geraghty P, Kavanagh K. 2003a Erythromycin, an inhibitor of mitoribosomal protein biosynthesis, alters the Amphotericin B susceptibility of Candida albicans. J Pharm Pharmacol 55, 179-184.

Geraghty P, Kavanagh K. 2003b Disruption of mitochondrial function in Candida albicans leads to reduced cellular ergosterol levels and elevated growth in the presence of Amphotericin B. Arch Microbiol 179, 295-300.

Igdaloff D, Santi DV, Eckert TS, Bruice TC. 1983. Effects of 1,7and 1,10-phenanthroline dione on tissue culture cells. Biochemical Pharmacol 32, 172-174.

Kelly SI, Lamb DC, Kelly DE, Manning NJ, Loeffier J, Herbart H, Schumacher U, Einsele H. 1997 Resistance to fluconazole and cross resistance to amphotericin $\mathrm{B}$ in Candida aibicans from AIDS patients caused by defective sterol $\Delta^{5,6}$ desaturation. FEBS Letts 400, 80-82.

McCann M, Geraghty M, Devereux M et al. 2000 Insights into the mode of action of the anti-Candida activity of 1,10phenanthroline and its metal chelates. Metal-Based Drugs 7, 185-193.

McCann M, Coyle B, McKay S, McCormack P, Kavanagh K, Devereux M, McKee V, Kinsella P, O’Connor R, Clynes M. Synthesis and X-ray crystal structure of $\left[\mathrm{Ag}(\text { phendio })_{2}\right] \mathrm{ClO}_{4}$ (phendio $=1,10$-phenanthroline-5,6-dione) and its effects on fungal and mammalian cells. Biometals (submitted).

Morschhauser J. 2002 The genetic basis of fluconazole resistance development in Candida albicans. Biochem Biophys Acta 1587, 240-248.

Parks LW, Casey WM. 1995 Physiological implications of sterol biosynthesis in yeast. Ann Rev Microbial 49, 95-116.

Vazquez JA, Arganoza MT, Vaishampayan JK, Akins RA. 1996 In vitro interaction between Amphotercin B and azoles in Candida albicans. Antimicrob Agen Chemother 40: 2511-2516.

White TC, Marr KA, Bowden RA. 1998 Clinical, cellular and molecular factors that contribute to anti-fungal drug resistance. Clin Microbiol Rev 11: 382-402. 